\title{
Plant-mediated bio-synthesis of silver-montmorillonite nanocomposite and antibacterial effects on gram-positive and -negative bacteria
}

\author{
Setareh Ghiassi ${ }^{1} \cdot$ Sajjad Sedaghat $^{2} \cdot$ Masoud Mokhtary $^{1} \cdot$ Hassan Kefayati $^{1}$
}

Received: 2 June 2018 / Accepted: 10 August 2018 / Published online: 31 August 2018

(c) The Author(s) 2018

\begin{abstract}
In this project, facile, rapid biosynthesis and characterization of silver-montmorillonite (MMT) nanocomposite is carried out at ambient temperature. Silver nanoparticles (Ag-NPs) were prepared by water extract of the plant [Satureja hortensis (L)] as the reducing agent and MMT as interlamellar space for controlling the size of Ag-NPs. MMT was sonicated in the aqueous $\mathrm{AgNO}_{3}$ solution and $\mathrm{Ag}^{+}$ions were reduced to $\mathrm{Ag}^{\circ}$ using water extract of Satureja hortensis $(\mathrm{L})$. The nanocomposite was evaluated using ultraviolet-visible spectroscopy (UV-Vis), X-ray diffraction (XRD), scanning electron microscopy (SEM) and transmission electron microscopy (TEM). TEM study showed the formations of nanocomposite using water extract of Satureja hortensis $\mathrm{L}$ in the range of 4.88-26.70 $\mathrm{nm}$ and an average particles size of $15.79 \mathrm{~nm}$. In addition, XRD studies indicated that the particles have a face centred cubic (FCC) structure. The nanocomposite showed antibacterial effects against bacteria.
\end{abstract}

\section{Graphical abstract}

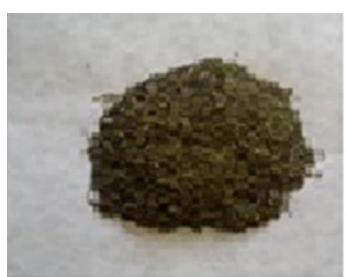

Satureja hortensis $L$
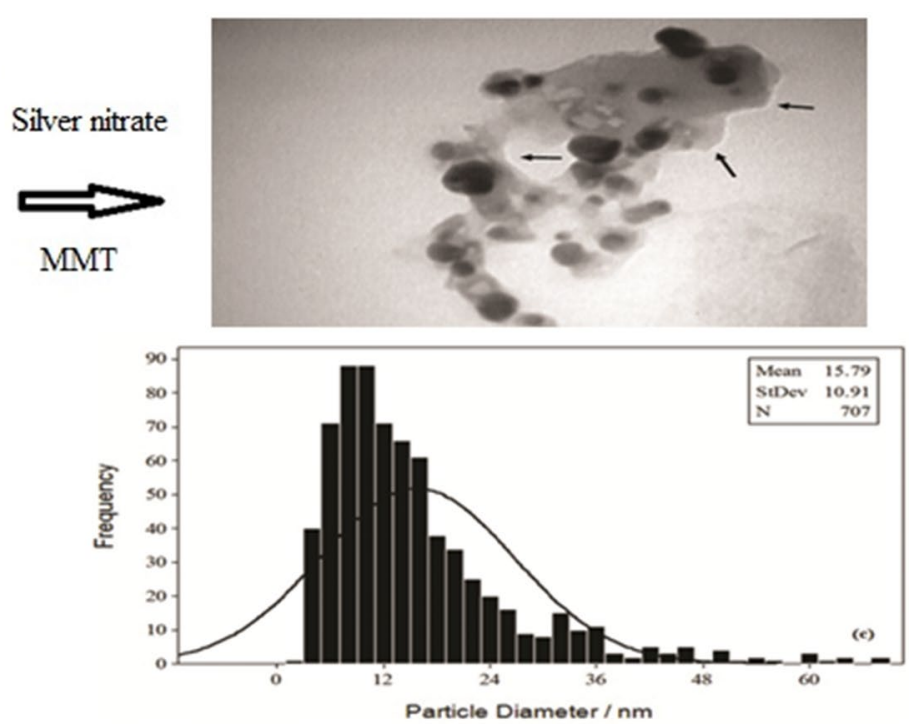

Keywords Antibacterial effects · Montmorillonite $\cdot$ Nanocomposite $\cdot$ Satureja hortensis L $\cdot$ Transmission electron microscopy

Sajjad Sedaghat

sajjadsedaghat@yahoo.com

Extended author information available on the last page of the article 


\section{Introduction}

Nanoparticles (NPs) synthesis have recently attracted much attentions; therefore, the synthesis of nano silver (Ag-NPs) has been a subject of great interest in the past several years [1]. Ag-NPs have good electrical, catalytical and medical applications. Because Ag-NPs do not have long life time in aqueous media and may agglomerate fast, to prevent this problem, NPs can be go between the MMT internal spaces or on its external surfaces [2]. So, the AgNPs can go onto MMT layers as a desired process to control the particle size. In particular, the interlayer space of MMT can be employed for the synthesis of metal NPs as discussed in our previous works [3-5]. The synthesis of $\mathrm{TiO}_{2}-$-montmorillonite nanocomposites into the interlayers of montmorillonite has also been successfully carried out [6]. Other research showed that Ag-NPs were prepared by chemical reduction into the interlayer of montmorillonite [7]. Silver-montmorillonite-starch nanocomposites were also synthesized using UV irradiation as the reducing agent, starch as the stabilizer and montmorillonite as a solid support [3]. Synthesis and evaluation of Ag-NPs by UV irradiation to silver nitrate in the interlayer of MMT using no reducing agent or heat process was also reported in other works [8]. Also platinum nanoparticles were also prepared using MMT and catalytic activities were evaluated [9]. The properties of biosynthesized silver nanoparticles were evaluated in other research [10].

Biological systems present in water extract of plants is good candidate to be used for the bio-reduction of $\mathrm{Ag}^{+}$ ions to Ag-NPs as a green chemical, via a cost-effective and environmentally friendly route [11]. In our previous work, Ag-NPs were successfully prepared with an average size of $15 \pm 7.4 \mathrm{~nm}$ by the water extract of this plant at ambient temperature without any support [12]. In this project, rapid and eco-friendly bio-reduction method for the synthesizing of Ag-NPs is reported. In this method, controlled and one pot reduction without any hazardous products is utilized. Ag-NPs were prepared into the lamellar space of MMT using water extract of Satureja hortensis L in ambient temperature. MMT was used to prevent nanoparticles from aggregation. The antibacterial effect of the nanocomposite was evaluated against Escherichia coli (Gram-negative) and Staphylococcus aureus (Grampositive) bacteria by the minimum bactericidal concentration $(\mathrm{MBC})$ method.

\section{Experimental}

\section{Materials and methods}

Chemicals were purchased from the Merck, Fluka and Aldrich chemical companies. All reagents were prepared as analytical grade. Double distilled water was also used in all experiments. Nicolet 370 FT-IR spectrometer, Philips $\mathrm{X}$-ray diffraction, cam scan MV2300 as scanning electron microscopy (SEM), Philips EM208 transmission electron microscope (TEM) were used in this project. The UV-visible spectra were also obtained using UV Bio-TEK UV-visible spectrophotometer from 300 to $800 \mathrm{~nm}$. The antibacterial tests were characterized using the minimum bactericidal concentration (MBC) method [13, 14].

\section{Preparing the water extract of plant}

Fresh plants were collected from Malard region of Iran in September 2017. Silver nitrate $(99.80 \%)$, used as the $\mathrm{Ag}^{+}$source, was purchased from Merck chemical co. and the MMT from Fluka chemical co. Kanamycin (antibiotic) was supplied by Duchefa Biochemie and vancomycin (antibiotic) was obtained from Sigma Aldrich chemical co. Fresh leaves of Satureja hortensis L were dried for a week in shade. The Satureja hortensis L dried leaves were extracted in water and used for reduction of $\mathrm{Ag}^{+}$ions to $\mathrm{Ag}^{\circ}$. For this purpose, $30 \mathrm{~g}$ of dried leaves of the plant was added to $100 \mathrm{~mL}$ of water and the mixture was heated for $20 \mathrm{~min}$ at $40{ }^{\circ} \mathrm{C}$. The obtained water extract was centrifuged at $3000 \mathrm{rpm}$ for $20 \mathrm{~min}$.

\section{Green biosynthesis of silver nanoparticles}

$0.01 \mathrm{~g}$ of clay was added in $50 \mathrm{~mL}$ of distilled water in $2 \mathrm{~h}$. Clay solution was poured to $100 \mathrm{~mL}$ of $0.01 \mathrm{mM}$ of $\mathrm{AgNO}_{3}$ solutions to prepare the $\mathrm{Ag} / \mathrm{MMT}$ nanocomposite. The prepared solution was then added to $40 \mathrm{~mL}$ of plant extract at ambient temperature for $48 \mathrm{~h}$ as mixing.

\section{Results and discussion}

\section{UV-Vis absorption measurements}

In Fig. 1, the UV-Vis spectra of Ag-NPs synthesized by the extract of Satureja hortensis L, clay and plant extract are illustrated $(\mathrm{a}-\mathrm{c})$. The SPR bands for silver particles are shown in the range of $350-420 \mathrm{~nm}$. These peaks are due to the Ag-NPs below $30 \mathrm{~nm}$. The peak near $400 \mathrm{~nm}$ is due to the formation of $\mathrm{Ag} / \mathrm{MMT}$ nanocomposite in nanometer 


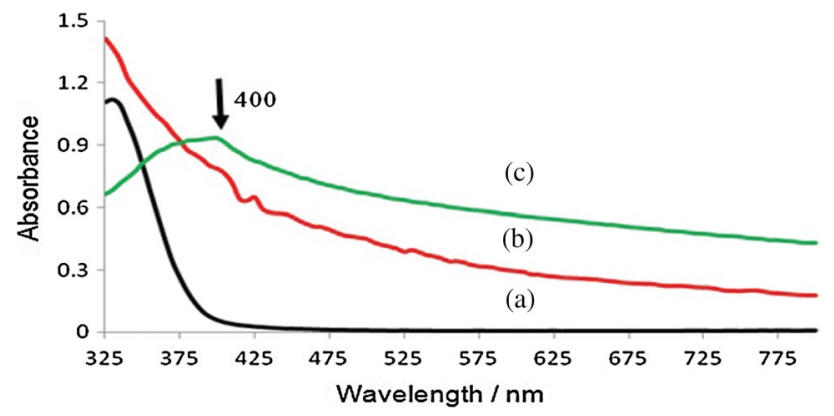

Fig. 1 UV-Vis spectra: a plant extract of Satureja hortensis L, b (MMT) and c Ag/MMT nanocomposite suspension in water after $48 \mathrm{~h}$

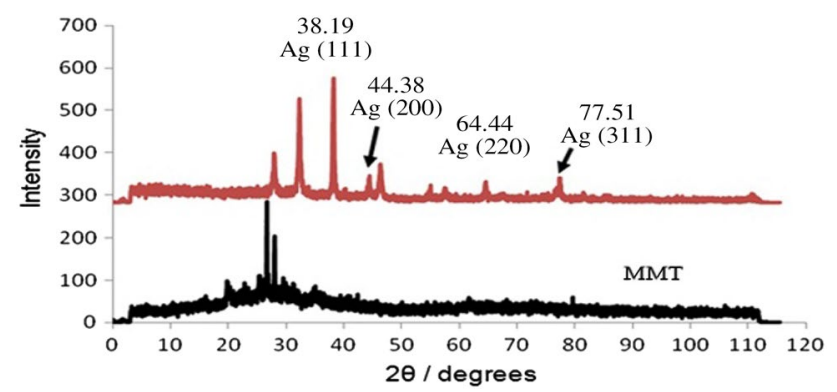

Fig. 2 XRD patterns of nano clay and Ag/MMT nanocomposite synthesized by Satureja hortensis L water extract after $48 \mathrm{~h}$

size which is in correlation with TEM results as $15.79 \mathrm{~nm}$ $[14,15]$.

\section{X-ray diffraction (XRD) patterns}

In Fig. 2 the XRD patterns of the pure montmorillonite and the synthesized $\mathrm{Ag} / \mathrm{MMT}$ nanocomposite are shown. In the $\mathrm{Ag} / \mathrm{MMT}$ nanocomposite, the XRD peaks at $2 \theta$ of $38.19^{\circ}$, $44.38^{\circ}, 64.44^{\circ}$ and $77.51^{\circ}$ correspond to (111), (200), (220) and (311) planes of the face centered cubic (FCC) of nanocomposite, respectively. The mean particle sizes of nanocomposites were characterized by the Debye-Scherer Eq. 1:

$d=\frac{K \lambda}{\beta \cos \theta}$

The average sizes of nanocomposites were calculated to be about $16 \mathrm{~nm}$.

\section{SEM and TEM observations}

SEM image of Ag/MMT nanocomposite, prepared by green reduction of $\mathrm{AgNO}_{3}$ in montmorillonite using water extract of Satureja hortensis L at room temperature, is shown in Fig. 3. SEM images were used to analyze the morphology of Ag/MMT nanocomposite. The shape of the

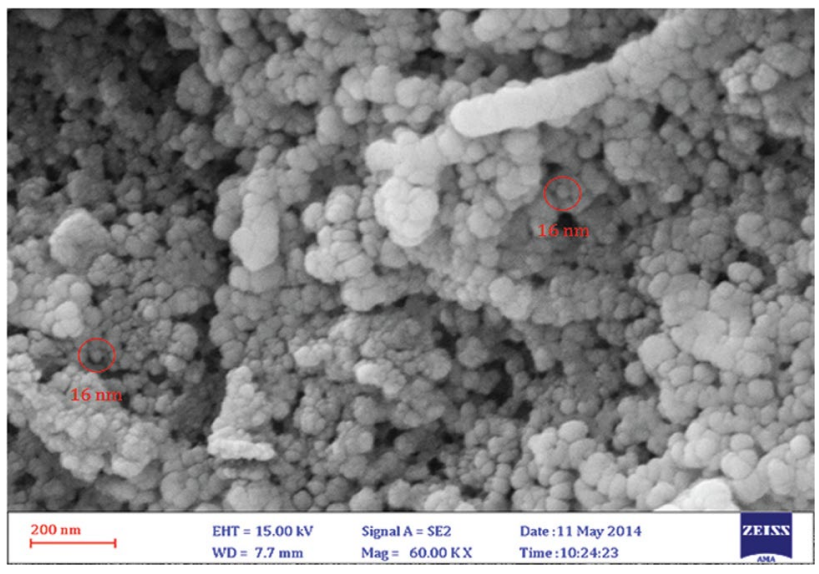

Fig. 3 SEM images of Ag/MMT nanocomposite
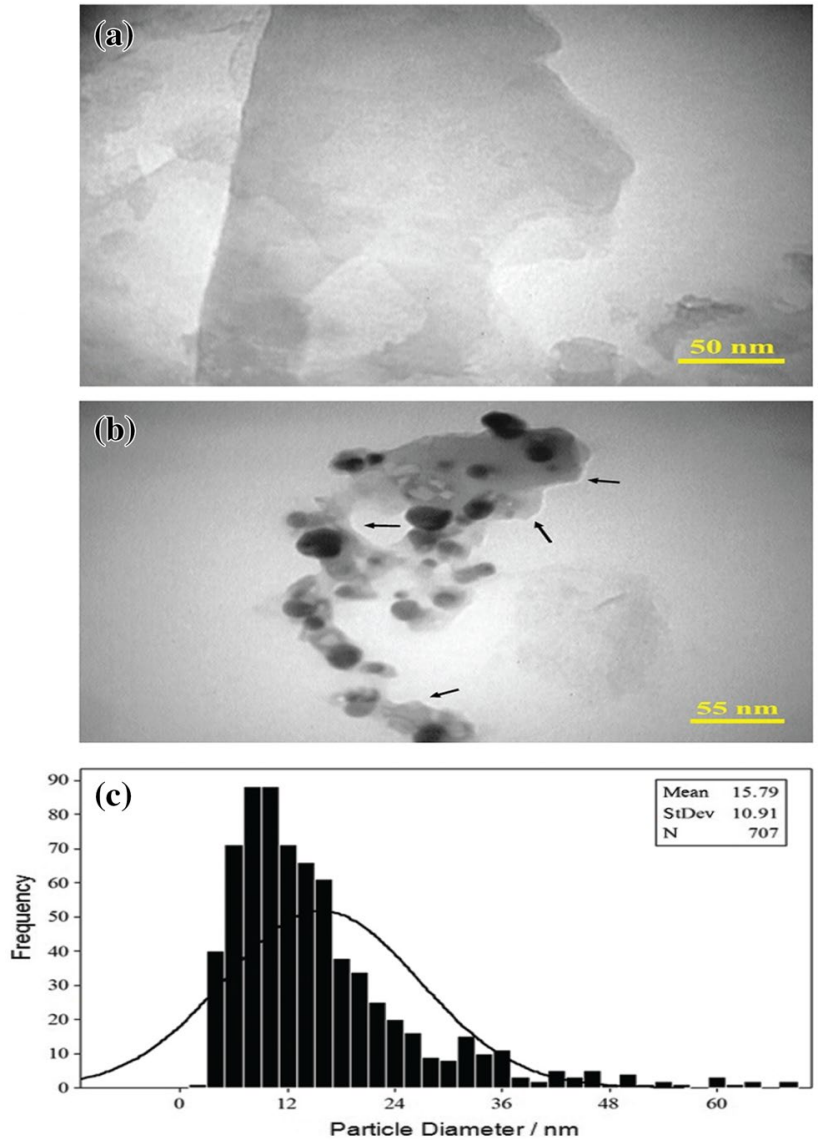

Fig. 4 TEM image: a montmorillonite, b Ag/MMT nanocomposite and corresponding size of Ag/MMT nanocomposite after $48 \mathrm{~h}$

particles was found to be spherical and their average size was about $16 \mathrm{~nm}$. Because of the structure of clay and the influence of silver ions onto these layers, the data confirm the formation of small silver NPs. 
The formation of Ag/MMT nanocomposite suspension was confirmed by the TEM image. Figure $4 a$, b show the TEM images of montmorillonite and nanocomposite, respectively, and Fig. 4c shows the size distribution of the $\mathrm{Ag} /$ MMT nanocomposite suspension. TEM image and the size distribution of Ag/MMT nanocomposite suspension show the mean diameter and $15.79 \pm 10.91 \mathrm{~nm}$ standard deviation of the nanocomposite for particles prepared in the montmorillonite layers. In addition, the TEM image confirmed the presence of a layer surrounding the nanocomposite, which prevented the agglomeration of the particles. These layer surroundings are depicted in the figure with black arrows.

\section{FT-IR spectroscopy}

In Fig. 5 the FT-IR spectra of clay, plant water extract and nanocomposite are shown. In MMT, the vibration band at $3634 \mathrm{~cm}^{-1}$ corresponds to $\mathrm{O}-\mathrm{H}$ stretching and the peak at $3440 \mathrm{~cm}^{-1}$ is related to the interlayered $\mathrm{O}-\mathrm{H}$ stretching. The interactions between MMT and Ag-NPs are indicated by the peak at $3440 \mathrm{~cm}^{-1}$. This peak is for the interaction between $\mathrm{OH}$ groups of clay layers and the positive charge of the silver

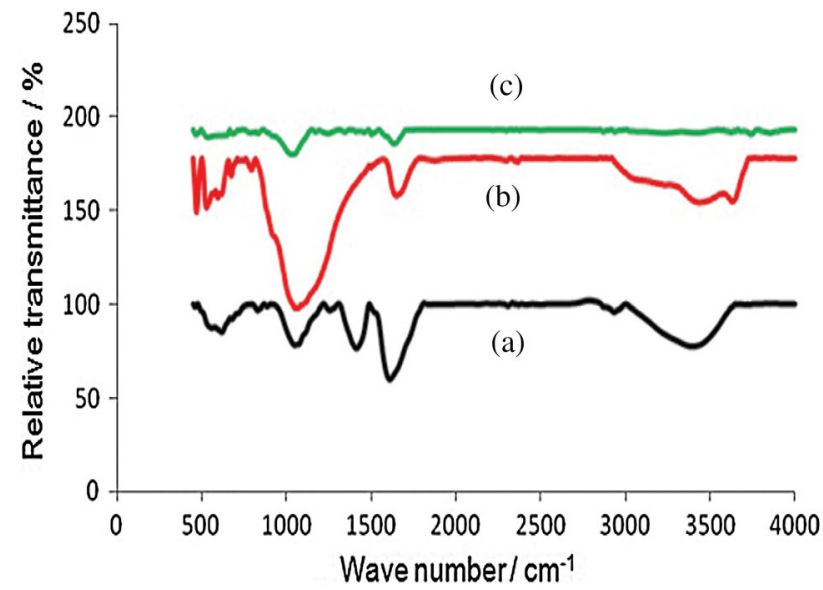

Fig. 5 FT-IR spectra: a plant extracts of Satureja hortensis L, b montmorillonite and c Ag/MMT nanocomposite after $48 \mathrm{~h}$
NPs [9]. Also FT-IR was used to evaluate the biomolecules are potentially present in extract and cane act as reducing and capping of the Ag-NPs, which can be attributed to the biomolecules consisting - $\mathrm{OH}$ functional groups.

\section{Antibacterial tests}

The antibacterial tests of Ag/MMT nanocomposite (which is purified by centrifugation) and Kanamycin and Vancomycin antibiotics against Escherichia coli and Staphylococcus aureus were successfully carried out [15]. The results showed that the optimum concentration was as shown in Table 1.

\section{Conclusions}

In summary, Ag/MMT nanocomposites were successfully obtained by a rapid, eco-friendly and biological process without using any toxic chemicals as the reducing agent at ambient temperature and their antibacterial properties were evaluated. The size of nanocomposite particles was between about $15 \pm 7.4 \mathrm{~nm}$. Ag/MMT nanocomposite was also confirmed by UV-Visible absorption spectra, TEM, SEM images. The TEM image showed that the Ag/MMT nanocomposites were of spherical shape and X-ray result confirmed that the obtained $\mathrm{Ag} / \mathrm{MMT}$ nanocomposites have a face centered cubic crystal structure. By size and shape controlling with MMT as inter layer, the prepared nanocopmpsite has good shape as spherical and prevented the agglomeration; so the antibacterial effects are improved. The antibacterial tests of Ag/MMT nanocomposites on Escherichia coli (gram-negative) and Staphylococcus aureus (grampositive) bacteria by the minimum bactericidal concentration (MBC) method were successfully carried out and the results showed that $\mathrm{Ag} / \mathrm{MMT}$ nanocomposite had strong antibacterial properties in compression with kanamycin nd vancomycin.

Table 1 Values of concentrations of antibiotics and nanocomposite against two bacteria

\begin{tabular}{|c|c|c|c|}
\hline \multirow[t]{2}{*}{ Compound } & \multicolumn{3}{|l|}{ Variable } \\
\hline & $\begin{array}{l}\text { (MBC) } \\
\text { dilution }\end{array}$ & $\begin{array}{l}\text { Initial concentration } \\
\left(\mu \mathrm{g} \mathrm{m}^{-1}\right)\end{array}$ & $\begin{array}{l}\text { Effective } \\
\text { concentra- } \\
\text { tion } \\
\left(\mu \mathrm{g} \mathrm{mL}^{-1}\right)\end{array}$ \\
\hline Kanamycin against Escherichia coli bacteria & $1: 32$ & 1000 & 31.25 \\
\hline Vancomycin antibiotic against Staphylococcus aureus bacteria & $1: 64$ & 256 & 4 \\
\hline Silver-montmorillonite nanocomposite against Escherichia coli bacteria & 1: 4096 & 792 & 0.193 \\
\hline Silver-montmorillonite nanocomposite against Staphylococcus aureus bacteria & $1: 4096$ & 792 & 0.193 \\
\hline
\end{tabular}


Acknowledgement This project is supported by Rasht and Shahr-eQods Branches of Islamic Azad University of Iran.

Open Access This article is distributed under the terms of the Creative Commons Attribution 4.0 International License (http://creativeco mmons.org/licenses/by/4.0/), which permits unrestricted use, distribution, and reproduction in any medium, provided you give appropriate credit to the original author(s) and the source, provide a link to the Creative Commons license, and indicate if changes were made.

\section{References}

1. Allafchian, A.R., Mirahmadi-Zare, S.Z., Jalali, S.A.H., Hashemi, S.S., Vahabi, M.R.: Green synthesis of silver nanoparticles using phlomis. J Nanostruct Chem 6, 129-135 (2016)

2. Azizi, M., Sedaghat, S., Tahvildari, K., Derakhshi, P., Ghaemi, A.: Synthesis of silver nanoparticles using Peganum harmala extract as a green route. Green Chem Lett Rev 10(4), 420-427 (2017)

3. Mansor Bin, A., Shameli, K., Darroudi, M.: Synthesis and characterization of silver/clay nanocomposites by chemical reduction method. Am J Appl Sci 6(11), 1909-1914 (2009)

4. Elemike, E.E., Onwudiwe, D.C., Mkhize, Z.: Eco-friendly synthesis of AgNPs using Verbascum thapsus extract and its photocatalytic activity. Mater Lett 185, 452-455 (2016)

5. Bagheriyan, S., Esmaeili, A., Sedaghat, S.: Biosynthesis of silver nanoparticles using Pennyroyal water extract as a green route. $\mathrm{J}$ Nanostruct Chem 6, 25-27 (2016)

6. Miao, Sh, Liu, Zh, Han, B., Zhang, J., Yu, X., Du, J., Sun, Zh: Synthesis and characterization of $\mathrm{TiO}_{2}$-montmorillonite nanocomposites and their application for removal of methylene blue. J Mater Chem 16, 579-584 (2006)

7. PinY, Shameli K., Miyake, M., Kuwano, N., Bahiyah, N., Ahmad, K., Mohamad, S., Lee, K.: Nanoscale. Res Lett 11(1), 276 (2016)
8. Darroudi, M., Ahmad, M.B., Shameli, K., Abdullah, A.H., Ibrahim, N.A.: Synthesis and characterization of UV-irradiated silver/montmorillonite nanocompositesynthesis. Sol State Sci 11, 1621-1624 (2009)

9. Manikandan, D., Divakar, D., Rupa, A.V., Revathi, S., Preethi, M.E.L., Sivakumar, T.: Synthesis of platinum nanoparticles in montmorillonite and their catalytic behavior. Appl Clay Sci 37, 193-200 (2007)

10. Bhagat, M., Rajput, S., Arya, S., Khan, S., Lehana, P.: Biological and electrical properties of biosynthesized silver nanoparticles. Bull Mater Sci 38(5), 1253-1258 (2015)

11. Khan, M.Z.H., Tareq, F.K., Hossen, M.A., Roki, M.N.A.M.: Green synthesis and characterization of silver nanoparticles using Coriandrum Sativum leaf extract. J Eng Sci Tech 13(1), 158-166 (2018)

12. Afshar, P., Sedaghat, P.: Bio-synthesis of silver nanoparticles using water extract of Satureja Hortensis L. evaluation of the antibacterial properties. Curr Nanosci. 12, 90-93 (2016)

13. Lopes, M., Oliveira, F.R., Malheiros, F.F., de Andrade, M.A., Monteiro, M.C., Baetas Gonçalves, A.C.: Antimicrobial bioassayguided fractionation of a methanol extract of Eupatorium triplinerve. Pharm Biol 53(6), 897-903 (2015)

14. Holla, G., Yeluri, R., Munshi, A.K.: Evaluation of minimum inhibitory and minimum bactericidal concentration of nano-silver base inorganic anti-microbial agent $\left(\right.$ Novaron $\left.^{\circledR}\right)$ against streptococcus mutans. Contemp Clin Dent 3, 288-293 (2012)

15. Sondi, S., Salppek, B.: Silver nanoparticles as antimicrobial agent: a case study on $E$. coli as a model for gram-negative bacteria. J Coll Interface Sci 275, 177-182 (2004)

Publisher's Note Springer Nature remains neutral with regard to jurisdictional claims in published maps and institutional affiliations.

\section{Affiliations}

\section{Setareh Ghiassi ${ }^{1}$. Sajjad Sedaghat ${ }^{2} \cdot$ Masoud Mokhtary $^{1} \cdot$ Hassan Kefayati $^{1}$}

1 Department of Chemistry, Faculty of Science, Rasht Branch, Islamic Azad University, Rasht, Iran
2 Department of Chemistry, Faculty of Science, Shahr-e-Qods Branch, Islamic Azad University, Tehran, Iran 